\title{
Customer Perceptions for Store Attributes: A Study of Unorganized Retail Stores in India
}

\author{
Hari Govind Mishra ${ }^{1^{*}}$, Surabhi Koul ${ }^{2}$ and Piyush Kumar Sinha ${ }^{3}$ \\ ${ }^{1}$ Assistant Professor, School of Business, Shri Mata Vaishno Devi University, Jammu, India \\ ${ }^{2}$ Research Scholar, College of management, School of Business, Shri Mata Vaishno Devi University, Jammu, India \\ 3 Indian Institute of Management, Ahmedabad, India
}

"Corresponding author: Dr. Hari Govind Mishra, Assistant Professor, School of Business, Shri Mata Vaishno Devi University, Jammu, India, Tel: +374 10 23-72-61; Email: govindhari1976@gmail.com

Received date: March 10, 2014, Accepted date: December 20, 2014, Published date: December 27, 2014

Copyright: ( 2014 Mishra HG, et al. This is an open-access article distributed under the terms of the Creative Commons Attribution License, which permits unrestricted use, distribution, and reproduction in any medium, provided the original author and source are credited.

\begin{abstract}
The objective of the study is to examine the store attributes for a traditional store in Indian context. The study we will evaluate the relationship between store attributes and customer perceptions in different retail categories in traditional stores. The study is a two staged study with its first stage as a set of qualitative based interviews leading the second stage of designing a structured questionnaire. A total of 240 structured questionnaires were collected to examine the data. Another significant relation which was evolved was the moderating effect on the relationship between distances travelled on the customer perceptions. The results identified typically stress on the positive relation between customer perceptions and store attributes. The relations identified and the recommendations made in the article would help the retailers catering in unorganized markets to meet the customer expectations and hence retain a loyal customer.
\end{abstract}

Keywords: Customer perceptions; Store attributes; Unorganized Stores

\section{Introduction}

Retail is defined as all the activities that involve selling of goods or services directly to the final consumer for their personal, non-business use via shops, market, door-to-door selling, and mail-order or over the internet where the buyer intends to consume the product. In 2004, The High Court of Delhi defined the term "retail" as a sale for final consumption in contrast to a sale for further sale or processing. Retailing can be defined as the activity that ensures that customers derive maximum value from the buying process. This involves activities and steps needed to place the merchandise made elsewhere into the hands of customers or to provide services to the customers. Thus the retail is an interface between the producer and the individual consumer buying for personal consumption. This excludes direct interface between the manufacturer and institutional buyers such as the government and other bulk customers.

The total concept and idea of shopping has undergone a vast drawing change in terms of format and consumer buying behavior, ushering in a revolution in shopping in India. Modern retailing has entered into India as is observed in the form of sprawling shopping centers, multi-storied malls and the huge complexes that offer shopping, entertainment and food all under one roof. The Indian retail industry has experienced growth of $10.6 \%$ between 2010 and 2012 and is expected to increase to USD $750-850$ billion by 2015 . With the emergence of the big players, the traditional kirana shops have also transformed themselves in different ways. A number of kirana shops have expanded in size allowing self-service and provide customers with deeper and wider assortments. These transformed kirana shops are now providing facilities like credit, replacement and home delivery [1]. Indian retail sector is gradually inching its way towards becoming the next boom industry. But still Indian retail industry constitutes only $8 \%$ of organized retail and remaining $92 \%$ is left unorganized. Unorganized retailing refers to the traditional forms of low cost retailing for example local kirana shops, owner operated shops, pan beedi shops, convenience shops, hand cart and street vendors Although there is a growth pattern in organized retailing and in its consumption made by the Indian population, still very huge traditional markets have held their base in Indian retail sector. The country's traditional retail industry is expected to grow at an average annual rate of $10 \%$ over the next year. There are about 12 million retail outlets spread across India, earning it the epithet of a "nation of shopkeepers" (Ernest and Young, 2012). More than 80\% of these 12 million outlets are run by small family businesses which use only household labour. Traditionally, small-store (kirana) retailing has been one of the easiest ways to generate self-employment, as it requires limited investment in land, capital and labor.

Much of the previous retail research studies have focused on the importance of store attributes in understanding the concept of store choice and patronage behavior [1] but majority of the research work is focused towards the organized retailing formats. Lindquist reviewed the published results of some 19 studies on retail store image and synthesized their frameworks into a set of six store image attributes. They are Merchandise, clientele, Promotions, service, Convenience, Store Atmosphere, Post Transaction Satisfaction. As Indian retail market is strongly driven by the unorganized (Traditional store) retail stores, so the current study deals with the importance of customer expectations for store attributes in unorganized retail scenario. This is an unexplored research area in an Indian context where few empirical studies have contributed to the existing knowledge of unorganized markets in India. Towards this end, this study and its outcome is a significant contribution to the field of Customer Perceptions and store choice behavior on the basis of store attributes literature in Indian 
retailing context. Hence, this study assumed significance aiming to examine the association between shoppers' perceptions and store attributes $s$ in food and grocery retailing in India. The geographical scope of the study is confined to the three districts of Jammu in Jammu and Kashmir in India. Another very important aspect to focus of the current study is the profiling of the traditional retail stores in these three districts. The end results would help us to evaluate the overall view of traditional stores on the basis of the type of merchandise they possess and the average square feet area.

\section{Literature Review}

\section{Demographics}

A few studies have examined the effect of consumer demographics on retail format choice in the grocery context. The behavior of shoppers differs according to the place where they are shopping and their involvement level with the act of shopping. Zeithaml conducted a field study to examine the effects of five demographic variables (gender, female working status, age, income, marital status) on supermarket shopping variables (e.g. shopping time, number of supermarkets visited weekly, amount of money spent. Demographic factors such as age, gender, marital status, income, female working status, education, occupation and family size exert enormous influence on choice of store format in grocery retailing [1] Fox et al. examined the effect of demographics on format choice across three formats: grocery stores, mass merchandisers, and drug stores. Findings from the study indicated that household size, income, and level of education influence consumers' format choices.

In our study we will evaluate the moderating effect of distance travelled on the customer perceptions. As the earlier literature suggests, the closer the consumers are to a store, the greater their likelihood to buy from that store. In contrast, the farther away consumers are from a store, the greater the number of intervening alternatives and thus the lower their likelihood to patronize that store. The travel time to a store is assumed to measure the effort, both physical and psychological, to reach a retail outlet. However, the effect of travel time varies by product. For some products, consumers are willing to travel very far. This study will help evaluate the moderating effect of distance travelled by the person to reach to the retail store and its perceptions for the store.

\section{Store attributes}

Store image: Doyle and Fenwick describe store image "The consumer's evaluation of all salient aspects of the store as individually perceived and weighted". The retail store has a "personality" composed of functional and psychological attributes. In most cases retail store image is represented by a multi-attribute construct. Literature focusing on various retail formats found different sets of store attributes to constitute what is defined as "image".

\section{Product assortment}

As shelf space in traditional retail stores is limited, the major assortment issues faced by a retailer include what products, and how many of each, should be on the shelves in the stores. In a classical economic sense, the assortment decision is easy, as the rational retailer should choose the combination of products that yields the biggest profit in the long run [2-20]. More products mean more flexibility and it gives the decision maker a sense of empowerment. A perception of a great assortment certainly influences store image and satisfaction with the store. The customer's perception on the quality of products and assortment are positively related to the patronage of a store as well as the perceived merchandise value. In addition, in a study in Greece, product assortment and quality were found to be the key drivers of customer's choice.

\section{Discounts}

Customers judge quality of a store and its image on the basis of the number and nature of the reduced price items in the store. Consumers have a perception of low overall prices of those stores that offer a small discount over a large number of items. Thus frequency of price advantage is stronger over magnitude of price advantage. A deep discount may induce some consumers who are loyal to the competing brands to switch to the promoted brand. It may also induce some consumers, who would have otherwise found the product category too expensive, to make a purchase in the product category. Larger discounts are likely to lead to an increase in variability in category sales. This is consistent with the analytical results in Magirou, Golabi, Helsen and Schmittlein, and Assuncao and Meyer. According to Ehrenberg et al., a sharp increase in sales was observed when price was first reduced followed by a return to near normal sales over time or offer end of the price.

\section{Retailers attitude}

In small traditional stores it has been seen that role of salesman is played by the retailer himself. Retailers relationship efforts are defined as "any effort that is actively made by a retailer towards a consumer, that is intended to contribute to the consumer's perceived value above and beyond the core product and/or service efforts received, and that can only be perceived by the consumer after continued exchange with the retailer". Hutheson and Muthinho [21-30] found that shoppers used a combination of quality of staff and the occurrence of low prices as the main variables in choosing a store. Salesperson can be seen as the extension of the store image and can play a significant role for repeat purchase and increasing satisfaction. According to Hawkins et al., the likelihood of interaction with sales person increases with the degree of involvement in purchase.

\section{Product availability}

Product availability, defined as the probability of having a product in stock when a customer order arrives, is one of the key performance components of customer service. When customers not find the products available they show different reactions ranging from switching store, brand or variant or to delaying or to even dropping the purchase. In their global study, Corsten and Gruen applied the five responses of, buy item at another store; delay purchase; substitute same brand; substitute - different brand; and do not purchase item. Kucuk studied how in-store merchandising and store attractiveness factors affect consumers' brand and store loyalty in out of stock situations. So, the availability of the product is a very important variable in developing an overall image of a store.

\section{Theoretical Model}

From the qualitative survey made with a sample of 40 customers and the extensive literature study, the six constructs that were derived were Store Image, product assortment, product availability, retailer attitude, discounts and extra benefits. A total of 28 statements were 
Page 3 of 9

derived which were used in a structured questionnaire and the data was collected. The conceptual model that was derived for the study is given in Fig1. The model developed has six hypotheses which are to be tested.

H1. Store image has a positive effect on customers' perception about the store.

H2. Product Assortment has a positive effect on the customers' perception about the store.

H3: product Availability has a positive effect on the customers' perception about the store.

H4: Retailers Attitude has a positive effect on the customers' perception about the store.

H5: Discounts has a positive effect on the customers' perception about the store.

H6: Other Services has a positive effect on the customers' perception about the store.

H7: Distance travelled by the customer has a moderating effect on the customers perception about the store attributes.

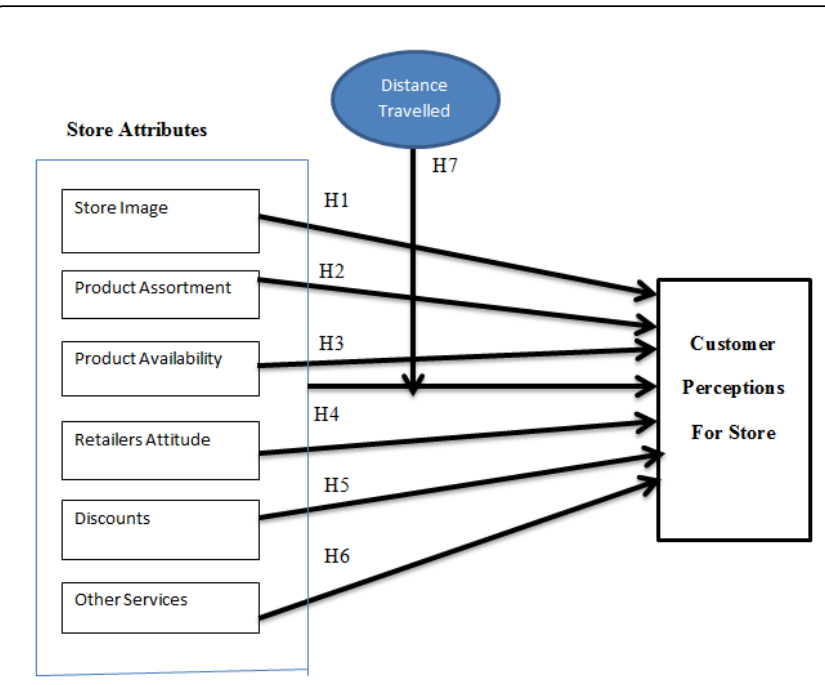

Figure 1: Conceptual Framework.

\section{Research Methodology}

The methodology adopted to seek the answers for the stated objectives was survey based. Due to the limited literature available on Customer perceptions on Indian context, the study has an exploratory nature identifying the customer Perceptions for store attributes in context of unorganized retail stores. Based upon the above parameters the study is designed to mainly answer the following questions:

Do these store attributes impact the customer perceptions about the retail store?

Do these perceived service attributes vary with the change in the product category?

Also to identify the moderating effect of "distance to be travelled" on customer perceptions.
The study was a two staged study with its first stage as a set of qualitative based interviews leading the second stage of designing a structured questionnaire. The study basically served to analyze whether there is an impact of store attributes in the consumers of unorganized markets in India. For this convenience based 40 semi structured interviews were conducted involving the consumers who dis their own shopping or at least were actively committed to the shopping (Including 17 females and 23 males of different age group, marital status and occupation). According to Glasser and Strauss, even if the sample size for qualitative interviews is small the exploratory nature and principle of saturation makes it sufficient to proceed for further research. The appropriate sample for qualitative study is the one that helps to reach a theoretical saturation where any additional data does not enrich or enhance the collected information.

The cues derived from the interviews helped us to design a structured questionnaire which helps in overall data collection. The step two of the study included designing of the structured questionnaire which consisted of 28 statements measured on a likert scale. The data was collected from rural areas of Jammu province of J and $\mathrm{K}$. the areas were selected on the basis of convenience from the Census 2011. Three sub districts of Jammu province were catered from where the questionnaires were filled from the consumers (Refer Table 1). The areas were selected on convenience based. The respondents were approached at the shop after they had finished shopping and were leaving the store. Due to a very conservative nature of villages very few persons per areas got ready to answer our questionnaires. So finally we got a total of 240 customers whose profile has been discussed in Table 2.

\begin{tabular}{|l|l|l|l|l|}
\hline S.No & Sub District & $\begin{array}{l}\text { Village } \\
\text { Code }\end{array}$ & Name of village & $\begin{array}{l}\text { No. } \\
\text { consumers } \\
\text { catered }\end{array}$ \\
\hline 1 & Akhnoor & 135 & Pallan Wala & 18 \\
\hline 2 & Akhnoor & 158 & Muthi & 21 \\
\hline 3 & Akhnoor & 178 & Chak Dhlan & 24 \\
\hline 4 & Akhnoor & 216 & Sidhar & 26 \\
\hline 5 & Jammu & 148 & Jaswan & 19 \\
\hline 6 & Jammu & 154 & Phalora Nagbani & 14 \\
\hline 7 & Jammu & 156 & Gura Brahmana & 19 \\
\hline 8 & Jammu & 157 & Patoli Brahmana & 18 \\
\hline 9 & Jammu & 163 & Chak Dina & 20 \\
\hline 10 & R.S Pora & 20 & Kadyal & 27 \\
\hline 11 & R.S Pora & 24 & Nari & 12 \\
\hline 12 & R.S Pora & 52 & Thikrian & 9 \\
\hline 13 & R.S Pora & 59 & Baspur & 13 \\
\hline
\end{tabular}

Table 1: Areas of Data collection.

A combination of descriptive and inferential statistical techniques was used to analyze the impact of store attributes on customer perceptions. Stepwise regression models were fit for each of the six levels of Store Attributes which are store image, product assortment, 
Page 4 of 9

product assortment, retailer's attitude, discounts and other services using a minimum inclusion alpha of.06.

\begin{tabular}{|c|c|c|}
\hline Gender & Total Number & Percentage \\
\hline Male & 92 & $38.40 \%$ \\
\hline Female & 148 & $61.66 \%$ \\
\hline \multicolumn{3}{|l|}{ Marital Status } \\
\hline Married & 157 & $65.40 \%$ \\
\hline Unmarried & 83 & $34.50 \%$ \\
\hline \multicolumn{3}{|l|}{ Age } \\
\hline $18-25$ & 62 & $25.80 \%$ \\
\hline $26-33$ & 89 & $37 \%$ \\
\hline $34-40$ & 54 & $22.50 \%$ \\
\hline$>40$ & 35 & $14.50 \%$ \\
\hline \multicolumn{3}{|l|}{ Occupation } \\
\hline Daily Wager & 128 & $53.30 \%$ \\
\hline Own Business & 53 & $22.08 \%$ \\
\hline Monthly earner & 59 & $24.60 \%$ \\
\hline \multicolumn{3}{|l|}{ Type of Store } \\
\hline Grocery & 65 & $27 \%$ \\
\hline Consumer durables & 32 & $13 \%$ \\
\hline Apparel & 17 & $7 \%$ \\
\hline Tobacco shops & 26 & $10 \%$ \\
\hline Chemist & 42 & $17 \%$ \\
\hline Cosmetics & 58 & $24 \%$ \\
\hline Total & 240 & \\
\hline \multicolumn{3}{|l|}{ Distance Travelled } \\
\hline $0.5 \mathrm{~km}$ & 68 & $28.30 \%$ \\
\hline $0.5-1 \mathrm{~km}$ & 45 & $18.70 \%$ \\
\hline $1-3 \mathrm{~km}$ & 41 & $17.08 \%$ \\
\hline $3-5 \mathrm{~km}$ & 36 & $15 \%$ \\
\hline $5-7 \mathrm{~km}$ & 32 & $13.30 \%$ \\
\hline More than $7 \mathrm{Kms}$ & 18 & $7.50 \%$ \\
\hline \multicolumn{3}{|l|}{ Frequency of purchase } \\
\hline Daily & 86 & $35.80 \%$ \\
\hline Weekly & 102 & $42.50 \%$ \\
\hline Monthly & 52 & $21.70 \%$ \\
\hline
\end{tabular}

Table 2: Customer Profiling (Quantitative Data).
Significance tests and beta estimates were used to evaluate the magnitude and direction of the effect(s) of the store attribute variables on customer perceptions. One way analysis of variance (ANOVA) was used to examine the effect of distance travelled on each of the six levels of store attributes among different categories beings selected. Levene's test for homogeneity of variance was evaluated for each of the ANOVA models.

\section{Data Analysis}

\section{Sample characteristics}

We obtained a total of 240 valid responses from the consumers. The profile of consumers is given in Table 2. In almost all cases the consumers were stopped after they had purchased from a retail store and told to fill up the questionnaire. For those it was difficult to analyze the questionnaire, we helped them to interpret the things. The sample was collected more carefully so that the consumers being selected represent the correct sample. So, the shop Exit Interview method was adopted. A total of 240 samples were collected with 38.4 females and $61.66 \%$ males. The customers were catered from the old format shops of grocery (27\%), cosmetics (24\%), chemist (17\%), consumer durables (13\%), Tobacco (10\%), (8.3\%), Apparel (7\%). Most of the sample was under daily earners $(53.3 \%)$ whereas a percentage of sample had their own business $(22.08 \%)$ and $24.08 \%$ were employed where they earned monthly. Nearly $35.8 \%$ customers shop daily from that retail store whereas $42.5 \%$ customer shops weekly and about $21.7 \%$ customers shop monthly. About $28.3 \%$ customers shop from a retailer which is with a radius of $0.5 \mathrm{~km}, 18.7 \%$ customers travel around $0.5-1 \mathrm{~km}$ distance, $17.08 \%$ customers travel $1-3 \mathrm{~km}$ distance, $15 \%$ customers travel $3-5 \mathrm{~km}$ distance, $13.3 \%$ customers travel about 5-7 $\mathrm{km}$ to visit a retail store whereas only $7.5 \%$ customers travel more than $7 \mathrm{~km}$ to purchase goods. This shows the buying behavior of customers of unorganized markets. They don't want to travel much distance to buy goods of daily usage.

\section{Store attributes and customer perceptions}

The effects of the store attribute variables including store image, product assortment, product assortment, retailer's attitude, discounts and other services on customer perceptions was evaluated using step by step regression. The results are shown in the Table 3.

\begin{tabular}{|l|l|l|l|l|l|}
\hline \multirow{2}{*}{$\begin{array}{l}\text { Predictor } \\
\text { Variable }\end{array}$} & \multicolumn{2}{|l|}{$\begin{array}{l}\text { Unstandardized } \\
\text { Coefficients }\end{array}$} & \multicolumn{2}{l|}{$\begin{array}{l}\text { Standardized } \\
\text { Coefficients }\end{array}$} & \multirow{2}{*}{ Significance } \\
\cline { 2 - 5 } & \multicolumn{2}{|l|}{ B S.E } & \multicolumn{2}{l|}{ B t } & \\
\hline Grocery & & & & & \\
\hline Constant & 3.515 & & & 23.654 & 0 \\
\hline Store image & 1.7 & 0.046 & & & 0.002 \\
\hline $\begin{array}{l}\text { Product } \\
\text { Assortment }\end{array}$ & 0.218 & 0.058 & & & 0 \\
\hline $\begin{array}{l}\text { Product } \\
\text { Availability }\end{array}$ & 0.095 & 0.431 & & & 0.004 \\
\hline $\begin{array}{l}\text { Retailers } \\
\text { Attitude }\end{array}$ & 0.113 & 0.475 & & & 0.001 \\
\hline Discounts & & & 0.004 & 0.114 & 0.912 \\
\hline
\end{tabular}


Citation: $\quad$ Mishra HG, Koul S, Sinha PK (2014) Customer Perceptions for Store Attributes: A Study of Unorganized Retail Stores in India. Bus Eco J 5: 127. doi:10.4172/2151-6219.1000127

Page 5 of 9

\begin{tabular}{|c|c|c|c|c|c|}
\hline Other Services & & & 0.035 & 0.683 & 0.0482 \\
\hline \multicolumn{6}{|l|}{$\begin{array}{l}\text { Consumer } \\
\text { Durables }\end{array}$} \\
\hline Constant & 3.219 & 0.147 & & 21.986 & 0 \\
\hline Store image & 0.094 & 0.046 & & & \\
\hline $\begin{array}{l}\text { Product } \\
\text { Assortment }\end{array}$ & & & 0.045 & 0.95 & 0.342 \\
\hline $\begin{array}{l}\text { Product } \\
\text { Availability }\end{array}$ & & & 0.036 & 0.765 & 0.453 \\
\hline $\begin{array}{l}\text { Retailers } \\
\text { Attitude }\end{array}$ & 0.095 & 0.048 & & & 0 \\
\hline Discounts & 0.097 & 0.047 & & & 0.004 \\
\hline Other Services & & & 0.031 & 0.712 & 0.532 \\
\hline \multicolumn{6}{|l|}{ Apparel } \\
\hline Constant & 1.341 & 0.103 & & 12.634 & 0 \\
\hline Store image & & & 0.034 & 0.732 & 0 \\
\hline $\begin{array}{l}\text { Product } \\
\text { Assortment }\end{array}$ & 0.066 & 0.019 & & & 0.003 \\
\hline $\begin{array}{l}\text { Product } \\
\text { Availability }\end{array}$ & & & 0.83 & 1.705 & 0.085 \\
\hline $\begin{array}{l}\text { Retailers } \\
\text { Attitude }\end{array}$ & 0.087 & 0.028 & & & 0.001 \\
\hline Discounts & 0.065 & 0.018 & & & 0.001 \\
\hline Other Services & & & 0.019 & 0.382 & 0.0602 \\
\hline \multicolumn{6}{|l|}{ Tobacco } \\
\hline Constant & 1.272 & 0.101 & & 12.646 & 0 \\
\hline Store image & & & 0.144 & 3.096 & 0.351 \\
\hline $\begin{array}{l}\text { Product } \\
\text { Assortment }\end{array}$ & & & 0.378 & 3.173 & 0.521 \\
\hline $\begin{array}{l}\text { Product } \\
\text { Availability }\end{array}$ & 0.076 & 0.023 & & & 0 \\
\hline $\begin{array}{l}\text { Retailers } \\
\text { Attitude }\end{array}$ & 0.071 & 0.021 & & & 0 \\
\hline Discounts & 0.045 & 0.013 & & & 0.002 \\
\hline Other Services & & & 0.176 & 2.95 & 0.459 \\
\hline \multicolumn{6}{|l|}{ Chemist } \\
\hline Constant & 1.577 & 0.179 & & 8.801 & 0 \\
\hline Store image & 0.09 & 0.04 & & & 0 \\
\hline $\begin{array}{l}\text { Product } \\
\text { Assortment }\end{array}$ & & & 0.016 & 2.991 & 0.697 \\
\hline $\begin{array}{l}\text { Product } \\
\text { Availability }\end{array}$ & 0.144 & 0.039 & & & 0 \\
\hline $\begin{array}{l}\text { Retailers } \\
\text { Attitude }\end{array}$ & 0.121 & 0.36 & & & \\
\hline
\end{tabular}

\begin{tabular}{|l|l|l|l|l|l|}
\hline Discounts & & & 0.011 & 2.845 & 0.499 \\
\hline Other Services & & & 0.076 & 1.564 & 0.117 \\
\hline Cosmetic & & & & & \\
\hline Constant & 3.762 & 0.157 & & 28.592 & 0 \\
\hline Store image & & & 0.932 & 1.945 & 0.548 \\
\hline $\begin{array}{l}\text { Product } \\
\text { Assortment }\end{array}$ & 1.567 & 0.092 & & & 0.001 \\
\hline $\begin{array}{l}\text { Product } \\
\text { Availability }\end{array}$ & 1.328 & 0.065 & & & 0 \\
\hline $\begin{array}{l}\text { Retailers } \\
\text { Attitude }\end{array}$ & 1.002 & 0.043 & & & 0 \\
\hline Discounts & & & 0.761 & 1.562 & 0.023 \\
\hline Other Services & & & 0.782 & 1.655 & 0.562 \\
\hline
\end{tabular}

Table 3: Predictor effects and beta estimates for store attributes in different categories of store.

The regression models were found to be significant within six product categories. The results indicated a varying consensus within every different category. In case of grocery, store image, product assortment, retailers attitude and product availability predict patronage with significance of $a<0.005$. Similarly in consumer durables category strong image, retailer attitude and discounts was found to be significant. In case of apparel and tobacco products product assortment, retailer's attitude and discounts was found to be significant. Whereas store image, product availability and retailers attitude was found significant in case of Chemist category [31-40]. Finally in the cosmetic category, product assortment, product availability and retailers attitude was found significant. Other services were found not found significant only in any of the categories. The height $\mathrm{t}$ - value was recorded for grocery category with a value of 23.654 at a significance of 0.000 .

\begin{tabular}{|l|l|l|l|l|l|l|}
\hline Effect & Grocery & $\begin{array}{l}\text { Consume } \\
\mathbf{r} \\
\text { Durables }\end{array}$ & Apparel & $\begin{array}{l}\text { Tobacc } \\
\mathbf{o}\end{array}$ & $\begin{array}{l}\text { Chemis } \\
\mathbf{t}\end{array}$ & $\begin{array}{l}\text { Cosmetic } \\
\mathbf{s}\end{array}$ \\
\hline $\begin{array}{l}\text { Store } \\
\text { Image }\end{array}$ & 2.456 & - & - & 1.569 & 1.732 \\
\hline $\begin{array}{l}\text { Product } \\
\text { Assortment }\end{array}$ & 1.483 & 1.769 & 1.653 & - & - & 1.998 \\
\hline $\begin{array}{l}\text { Product } \\
\text { Availability }\end{array}$ & 1.275 & - & 1.782 & 1.82 & 1.967 & 1.62 \\
\hline $\begin{array}{l}\text { Retailers } \\
\text { Attitude }\end{array}$ & 2.129 & - & - & 1.662 & 2.762 & - \\
\hline Discounts & - & 2.183 & 2.138 & - & - & - \\
\hline $\begin{array}{l}\text { Other } \\
\text { Services }\end{array}$ & - & - & - & 2.653 & - & - \\
\hline
\end{tabular}

Table 4: Multi Nominal Logit.

A multi nominal logit was carried out using these macro variables for understanding the customer perceptions for store attributes in different categories. In case of Grocery products customers mainly emphasize on product assortment, product availability and retailers 
attitude. This reflects that the customers in case of grocery products go to a known retailer and trust him for the purchases. Retailer's behavior impacts the customers to a large extent. Also the availability of their preferred product and the number of brands and variants the retailer carries also affects the customers and their purchase behavior. Whereas when we look at the consumer durable products customers mainly emphasize on the store image, product assortment and Discounts offered by the retailer to him. This shows that in case of consumer durables customer goes to a known retailer or a retailer who has a good image in market. Moreover consumer durables being high in price customer looks for a discount.

In case of Apparel customer looks for product assortments, product availability and Discounts offered at the store. They prefer those stores which have high depth and width of products. Customers look for high variety. The customers purchasing tobacco products look for product availability, retailer's attitude and other services. The reason behind this may be the choice and preference of such goods is fixed so they look for the preferred product at the store. Similar in case of cosmetic stores customer's looks for store image, product assortment, product availability. This is due to the nature of buying different varieties the customer looks for large assortments and availability at the store.

\section{Model testing}

The model illustrated in Figure 1 was tested using structural equation modeling in LISREL 8 . The overall fit statistics demonstrate acceptable model fit $\left(\mathrm{CFI}=.989, \mathrm{NFI}=.979, \mathrm{RMSEA}=.053, \chi^{2}=392.44\right.$ with $\mathrm{df}=181$ ). Following basic descriptive analyses (including examination for normality, skewness, and kurtosis), we did a confirmatory factor analysis (CFA) using LISREL 8. Items were grouped into a priori conceptualized constructs (see Table 5). The CFA overall fit was acceptable (CFI $=.991, \mathrm{NFI}=.982$, RMSEA $=.050$, $\chi^{2}=353.04$ with $174 \mathrm{df}$ ). Convergent validity was assessed by examining the magnitude, direction, and statistical significance of the estimated standardized factor loadings [41-45]. All the significant and positive factor loadings are being given (Table 5). In addition, Table 4 shows average variance extracted (AVE) and the reliabilities; all criteria as outlined by Gerbing and Anderson were met, supporting reliability. The construct reliability for Store image (0.904), Product Assortment (0.954), Product Availability (0.933), Retailers attitude (0.920), Discounts (0.970) and other services (0.901) was significantly large. We also assessed discriminant validity. Fornell and Larcker argued that the AVE of any two constructs should be greater than their squared correlation. Table 6 provides the supportive evidence. We also used nested models, successively fixing correlations (phi's) to 1 [46-48]. We evaluated one pair of factors at a time, and found support for discriminant validity.

\begin{tabular}{|l|l|l|l|}
\hline Construct & Measures & Loadings & AVE \\
\hline Store Image & $\begin{array}{l}\text { 1. I prefer the store } \\
\text { with good } \\
\text { reputation. } 0.803\end{array}$ & \multirow{2}{*}{0.769} \\
\hline C.R=0.904) & $\begin{array}{l}\text { 2. The store I visit } \\
\text { has a good } \\
\text { reputation in } \\
\text { society. } 0.782\end{array}$ & $\begin{array}{l}\text { 3. I rely on my store } \\
\text { for the goods I } \\
\text { purchase. }\end{array}$ & 0.888 \\
\hline
\end{tabular}

\begin{tabular}{|c|c|c|c|}
\hline Product Assortment & $\begin{array}{l}\text { 1. The store I visit } \\
\text { has almost all the } \\
\text { varieties of goods. }\end{array}$ & 0.91 & \multirow{5}{*}{0.874} \\
\hline \multirow[t]{4}{*}{ (C.R. $=0.954)$} & $\begin{array}{l}2 . \\
\text { product variety } 1 \\
\text { demand to the } \\
\text { retailer he has it in } \\
\text { the store. }\end{array}$ & 0.908 & \\
\hline & $\begin{array}{l}3 . \quad \text { When the } \\
\text { product is not at } \\
\text { store I tell my } \\
\text { retailer to get the } \\
\text { product he gets I } \\
\text { for me. }\end{array}$ & & \\
\hline & $\begin{array}{l}\text { 4. I hardly have to } \\
\text { visit other stores } \\
\text { because I get all } \\
\text { my goods from my } \\
\text { retail store. }\end{array}$ & 0.932 & \\
\hline & & 0.805 & \\
\hline Product Availability & $\begin{array}{l}\text { 1. Whenever I go to } \\
\text { store he has the } \\
\text { goods available } \\
\text { with him. }\end{array}$ & 0.897 & \multirow{4}{*}{0.862} \\
\hline \multirow[t]{3}{*}{ (C.R. $=0.933)$} & $\begin{array}{l}\text { 2. My retailer never } \\
\text { says no when I ask } \\
\text { him for the product. }\end{array}$ & & \\
\hline & $\begin{array}{l}\text { 3. The right product } \\
\text { in right packaging is } \\
\text { available at the } \\
\text { store. }\end{array}$ & 0.939 & \\
\hline & & 0.845 & \\
\hline Retailers Attitude & $\begin{array}{l}\text { 1. The retailer talks } \\
\text { to me in a helping } \\
\text { way. }\end{array}$ & 0.833 & \multirow{5}{*}{0.848} \\
\hline \multirow[t]{4}{*}{-0.92} & $\begin{array}{l}\text { 2. Whenever the } \\
\text { product is not at } \\
\text { store he gets it for } \\
\text { me in future. }\end{array}$ & 0.803 & \\
\hline & $\begin{array}{l}\text { 3. My retailer gives } \\
\text { me products on } \\
\text { credit basis also. }\end{array}$ & & \\
\hline & $\begin{array}{l}\text { 4. My retailer } \\
\text { shows me all } \\
\text { possible varieties } \\
\text { he has with him. }\end{array}$ & 0.955 & \\
\hline & & 0.872 & \\
\hline Discounts & $\begin{array}{l}\text { 1. He offers me } \\
\text { small discounts on } \\
\text { my purchases. }\end{array}$ & 0.925 & \multirow{3}{*}{0.915} \\
\hline \multirow[t]{2}{*}{$(C . R=0.970)$} & $\begin{array}{l}\text { 2. Whenever I buy } \\
\text { goods in large } \\
\text { quantities he gives } \\
\text { me certain money } \\
\text { off on total amount. }\end{array}$ & 0.978 & \\
\hline & $\begin{array}{lr}3 . \quad \text { The usually } \\
\text { keeps value packs } \\
\text { with him so that his } \\
\text { customer gets } \\
\text { benefitted. }\end{array}$ & & \\
\hline
\end{tabular}


Citation: Mishra HG, Koul S, Sinha PK (2014) Customer Perceptions for Store Attributes: A Study of Unorganized Retail Stores in India. Bus Eco

Page 7 of 9

\begin{tabular}{|c|c|c|c|}
\hline & & 0.966 & \\
\hline Other services & $\begin{array}{l}\text { 1. My retailer gives } \\
\text { me goods on credit. }\end{array}$ & 0.805 & \multirow{4}{*}{0.739} \\
\hline \multirow[t]{3}{*}{ (C.R=0.901) } & $\begin{array}{l}\text { 2. When I buy } \\
\text { goods in large } \\
\text { quantities res } \\
\text { delivers them to my } \\
\text { house. }\end{array}$ & 0.867 & \\
\hline & $\begin{array}{l}\text { 3. He takes my } \\
\text { product orders on } \\
\text { phone also. }\end{array}$ & & \\
\hline & & 0.842 & \\
\hline
\end{tabular}

Table 5: Measures, Loadings, Average Variance Explained (AVE) and Construct Reliability (CR).

\begin{tabular}{|l|l|l|l|l|l|l|}
\hline & $\begin{array}{l}\text { Store } \\
\text { Imag } \\
\mathbf{e}\end{array}$ & $\begin{array}{l}\text { Product } \\
\text { Assortme } \\
\text { nt }\end{array}$ & $\begin{array}{l}\text { Product } \\
\text { Availabilit } \\
\mathbf{y}\end{array}$ & $\begin{array}{l}\text { Retailer } \\
\mathbf{s} \\
\text { Attitude }\end{array}$ & $\begin{array}{l}\text { Discount } \\
\mathbf{s}\end{array}$ & $\begin{array}{l}\text { Other } \\
\text { service } \\
\mathbf{s}\end{array}$ \\
\hline $\begin{array}{l}\text { Store } \\
\text { image }\end{array}$ & 0.769 & & & & & \\
\hline $\begin{array}{l}\text { Product } \\
\text { Assortmen } \\
\mathrm{t}\end{array}$ & 0.239 & 0.874 & & & & \\
\hline $\begin{array}{l}\text { Product } \\
\text { Availability }\end{array}$ & 0.468 & 0.627 & 0.862 & & & \\
\hline $\begin{array}{l}\text { Retailers } \\
\text { Attitude }\end{array}$ & 0.223 & 0.489 & 0.59 & 0.848 & & \\
\hline Discounts & 0.108 & 0.12 & 0.239 & 0.482 & 0.915 & \\
\hline $\begin{array}{l}\text { Other } \\
\text { Services }\end{array}$ & 0.055 & 0.082 & 0.135 & 0.137 & 0.051 & 0.739 \\
\hline
\end{tabular}

Table 6: Discriminant Validity Analysis: ${ }^{\star}$ Based on Fornell and Larcker, 1998; AVE in the diagonal and squared correlations offdiagonal.

\begin{tabular}{|l|l|l|l|}
\hline Hypothesis Path & S.E & P-value & Conclusion \\
\hline H1: SI CP & 0.743 & $P<.01$ & Supported \\
\hline H2: PA CP & 0.789 & $P<.01$ & Supported \\
\hline H3: PAv CP & 0.847 & $P<.01$ & Supported \\
\hline H4: RA CP & 0.666 & $P<.01$ & Supported \\
\hline H5: DS CP & 0.701 & $P<.01$ & Supported \\
\hline H6: OS CP & -0.034 & n.s & Not supported \\
\hline
\end{tabular}

Table 7: Tests of the Hypotheses in Figure 1.

SI=Store Image

$\mathrm{PA}=$ Product Assortment

$\mathrm{PAv}=$ Product Availability

RA=Retailers Attitude

DS=Discount

OS=other services

\begin{tabular}{|c|c|c|c|}
\hline & STEP 1 & STEP 2 & STEP 3 \\
\hline Variables & B tp & $B t p$ & Btp \\
\hline Store Image & $\begin{array}{l}.451 \\
3.825 .000\end{array}$ & .2812 .289 .000 & .0843 .558 .000 \\
\hline $\begin{array}{l}\text { Product } \\
\text { Assortment }\end{array}$ & $\begin{array}{l}.473 \\
4.027 .000\end{array}$ & .240.112.002 & .068 .262 .000 \\
\hline Product Availability & $\begin{array}{l}.433 \\
3.256 .002\end{array}$ & .227 .876 .001 & .0871 .234 .000 \\
\hline Retailers Attitude & $\begin{array}{l}.369 \\
2.585 .001\end{array}$ & .008 .651 .000 & .0471 .451 .000 \\
\hline Discounts & $\begin{array}{l}.471 \\
4.014 .000\end{array}$ & .255 .788 .000 & .5154 .232 .000 \\
\hline Other Services & $\begin{array}{l}.488 \\
4.036 .001\end{array}$ & .261 .791 .001 & .5494 .321 .000 \\
\hline $\begin{array}{l}\text { Store Imagex } \\
\text { Customer } \\
\text { Perception }\end{array}$ & & & 1.451 .988 .002 \\
\hline $\begin{array}{l}\text { Product } \\
\text { Assortment } \\
\text { Customer } \\
\text { Perception }\end{array}$ & & & .2231 .775 .001 \\
\hline $\begin{array}{l}\text { Product } \\
\text { Availabilityx } \\
\text { Customer } \\
\text { Perception }\end{array}$ & & & .2231 .775 .001 \\
\hline $\begin{array}{l}\text { Retailers Attitudex } \\
\text { Customer } \\
\text { Perception }\end{array}$ & & & .023 .505 .090 \\
\hline $\begin{array}{l}\text { Discounts } \times \\
\text { Customer } \\
\text { Perception }\end{array}$ & & & .2512 .059 .000 \\
\hline $\begin{array}{l}\text { Other Services } \times \\
\text { Customer } \\
\text { Perception }\end{array}$ & & & .073.982.0528 \\
\hline Constant & $\begin{array}{l}5.374 \\
45.92 .000\end{array}$ & 5.38247 .696 .000 & 10.267 .427 .000 \\
\hline R2 & 0.164 & 0.233 & 0.299 \\
\hline Adjusted R2 & 0.148 & 0.213 & 0.267 \\
\hline$F$ value & 10.363 & 11.923 & 9.387 \\
\hline
\end{tabular}

Table 8: Moderated Regression Analysis.

The results in Table 7 indicate the model testing results for which the hypothesis were rejected or supported. According to the results, Store Image has a significant relationship $(\mathrm{p}<0.01)$ with customer perceptions and thus supports hypothesis 1 . Product assortment also had a significant relationship $(\mathrm{p}<0.01)$ with customer perceptions supporting Hypothesis 2. Similarly Product availability, retailer's attitude and discounts were found to be significant supporting hypothesis $\mathrm{H} 3, \mathrm{H} 4, \mathrm{H} 5$ respectively. The results can be properly analyzed through Table 7.

Entering the independent variables, the moderator, and the interaction terms in the multiple regression generated R-square of.299 
Page 8 of 9

$(\mathrm{F}=9.387, \mathrm{p}=002)$. It was hypothesized that distance travelled would moderate the relationship between store attributes and Customer Perceptions. As represented in Table 8 the interaction term of store image, product assortment, product availability, retailer's attitude, discounts and other services in step 3 was statistically significant.

Store image, product assortment, product availability and discounts with Customer perception were found significant with $t$ values $(1.988,1.775,2.765$ and 2.059$)$ respectively. But other services and retailers attitude were not found significantly moderating the customer perceptions as the significance level was $>0.05$. So the results show that Distance Travelled by customer shows a moderating effect on store image, product assortment, product availability and discounts but not on other services and retailer attitude. So, proving the hypotheses H7, the relation between Customer Perceptions stores attributes (store image, product assortment, product availability, and discounts) are being moderated by the distance travelled by customer.

\section{Implications}

As analyzed from the study the Indian retail market is strongly driven by the unorganized (Traditional store) retail stores and our aim was to deal with the importance of customer expectations for store attributes in unorganized retail scenario. The general customer profiles easily reflect that the customers visiting the unorganized store usually visit it for grocery products. Moreover such customers do not travel much to visit the retail store. As per the responses obtained store attributes have a very strong relationship with the customer perceptions in unorganized markets. Discounts showed the strongest relation, product assortment and product availability almost equally showed a strong relationship with customer perceptions. Then the Retailers attitude, strong Image and other services showed the relationship. The results reflect that the retailers in unorganized markets have to cater a customer which is more price sensitive and get attracted towards the discounts being offered to him. More over a typical emphasis should be given on the product assortment in the store and the availability of the desired goods of the customers. The predictor tests (Table 3 ) reveal that the customer purchasing grocery and consumer durable goods emphasize more on store attributes rather than in chemist or cosmetic products.

Table 4 shows the identified store attributes in each category being selected. The results show that the customers purchasing grocery products emphasize of store attributes like product assortment, product availability and retailers attitude. Similarly for other categories different store attributes emphasize different product categories. So, Retailers in unorganized markets should dealing with different categories should emphasize on different store attributes depending upon the type of customers he deals with. Another very important result of the study is the moderating effect of the "distance travelled by the customer to reach the store" on the customer perceptions. The results emphasized that the except Retailers attitude and the other services all other store attributes showed a significant relation with customer perceptions when moderated with the Distance travelled. These finding strongly emphasize that when customer wants prefers store attributes he even travels long distances to purchase that product. This also reflects the store loyalty factor of the customer. All these when kept under consideration can surely meet customer expectations and thus make your customer loyal.

\section{References}

1. Sinha PK, Banerjee A (2004) "Store choice behaviour in an evolving market". Int J of Retail and Distribution Manage 32: 482-94.

2. Anderson JC, Gerbing DW (1988) Structural equation modeling in practice: A review of the two-step approach. Psychological Bulletin 103: 53-66.

3. Arnold S (1997) "Shopping habits at Kingston department stores: wave III: three years after Wal-Mart's entry into Canada", Report No. 3, Queen's University School of Business, Kingston

4. Assuncao J, Robert JM (1990) "The Rational Effect of Price Expectations on Sales-Price Relationships," Working Paper, John E. Anderson Graduate School of Management, University of California, Los Angeles

5. Baltas G, Papastathopoulou P (2003) "Shopper characteristics, product and store choice criteria: a survey in the Greek grocery sector", Int J of Retail and Distribution Manage 31: 498-507.

6. Bawa K, Ghosh A (1999) "A model of household grocery shopping behavior". Marketing Letters 10: 149-60.

7. Bellenger DN, Korgaonkar PK (1980) "Profiling the recreational shopper". J of Retailing 56: 77-92.

8. Berman B, Evans JR (2005) Retail Management-A Strategic Approach, New Delhi, 8th ed., Pearson Education, Singapore.

9. Boatwright, Peter, Joseph CN (2001) "Reducing Assortment: An Attribute- Based Approach," J of Marketing 65: 50-63.

10. Chopra S, Meindl P (2007) Supply Chain Management: Strategy Planning and Operation, 3 ed., Pearson Prentice-Hall, Upper Saddle River, NJ.

11. Craig S, Ghosh A, McLafferty S (1984) "Models of retail location process: a review", J of Retailing 60: 5-36.

12. Corsten D, Gruen T (2003) "Desperately seeking shelf availability: an examination of the extent, the causes, and the effort to address retail outof-stock". Int J of Retail and Distribution Manage 31: 605-17.

13. Dabholkar PA, Thorpe DI, Rentz JO (1996) A measure of service quality for retail stores: Scale development and validation. J of the Academy of Marketing Science 24: 3-16.

14. Darley WK, Jeen-Su L (1993) "Store-choice behavior for pre-owned merchandise", J of Bus Res 27: 17-31.

15. East R (1997) Consumer Behavior: Advances and Applications in Marketing, Prentice-Hall, London.

16. Ehrenberg ASC, Hammond K, Goodhardt GJ (1994) The After-Effects of Price-Related Consumer Promotions. J of Advertising Res 34: 11-21.

17. Fox E, Montgomery A, Lodish L (2004) "Consumer shopping and spending across retail formats". J of Bus 77: 25-S60.

18. Fornell C, Larcker DF (1981) Evaluating structural equation models with unobservable variables and measurement error. JMR, J of Marketing Res 18: 39-50.

19. Gerbing DW, Anderson JC (1992) An updated paradigm for scale development incorporating unidimensionality and its assessment. JMR, J of Marketing Res 25: 186-192.

20. Glaser B, Strauss A (1967) The Discovery of Grounded Theory. Aldine Publishing Company, Hawthorne, NY.

21. Grewal, Dhruv, Kent B, Monroe, Krishnan R (1998) "The Effects of PriceComparison Advertising on Buyers' Perceptions of Acquisition Value, Transaction Value and Behavioral Intentions." J of Marketing 62: 46-59.

22. Grewal D, Baker J, Levy M, Voss GB (2003) "The effects of wait expectations and store atmosphere evaluations on patronage intentions in service-intensive retail stores". J of Retailing 79: 259-68.

23. Golabi, Kamal (1985) "Optimal Inventory Policies When Ordering Prices Are Random," Operations Research 33: 575-588.

24. Gwinner KP, Gremler DD, Bitner MJ (1998) "Relational benefits in services industries: the consumer's perspective". J of the Academy of Marketing Science 26: 101-14.

25. Hawkins DI, Best RJ, Coney KA (1998) Consumer Behavior: Building Marketing Strategy, 7th ed., McGraw Hill, Boston. 
Citation: $\quad$ Mishra HG, Koul S, Sinha PK (2014) Customer Perceptions for Store Attributes: A Study of Unorganized Retail Stores in India. Bus Eco J 5: 127. doi:10.4172/2151-6219.1000127

Page 9 of 9

26. Helsen, Kristiaan, Schmittlein D (1989) "Some Characterizations of Stockpiling Behavior under Un-certainty," Working Paper, The Wharton School of The University of Pennsylvania.

27. Jacoby J, Mazursky D (1985) “The impact of linking brand and retailer images on perceptions of quality”, in Jacoby, J. and Mazursky, D. (Eds), Perceived Quality: How Consumers View New Stores and Merchandise, D.C. Heath and Company, Lexington, MA, pp. 155-9.

28. Kahn, Barbara E. Donald R (1991) "Modeling Choice among Assortments," J of Retailing, 67: 274-99.

29. Koelemeijer K, Oppewal H (1999) "Assessing the effects of assortment and ambience: a choice experimental approach". J of Retailing 75: 319-45.

30. Koopmans, Tjalliong C (1964) "On the Flexibility of Future Preferences," in Human Judgments and Optimality, ed. M. W. Shelly and G. L. Bryan, New York: John Wiley and Sons, 243-56.

31. Kopp R, Eng,RJ, Tigert DJ (1989) "A competitive structure and segmentation analysis of the Chicago fashion market". J of Retailing 65: 496-516.

32. Kreps, David M (1979) "A Representation Theorem for Preference for Flexibility,"Econometrica 47: 565-77.

33. Kucuk SU (2004) "Reducing out-of-stock costs in a developing retailer sector”. J of Int Consumer Marketing 16: 75-104.

34. Kucuk SU (2008) "Can distribution explain double jeopardy patterns". Int J of Retail and Distribution Manage 36: 409-25.

35. Loudon DL, Della Bitta AJ (1993) Consumer Behavior: Concepts and Applications, McGraw-Hill, New York, NY.

36. Magirou, Vangelis F (1982) "Stockpiling under Price Uncertainty and Storage Capacity Constraints," European J of Operations Res11: 233-246.
37. Mason N (1996) Store Loyalty - That Old Chestnut, Nielsen Research, Oxford, pp. 6-15.

38. McGoldrick PJ, Andre E (1997) "Consumer misbehaviour: promiscuity or loyalty in grocery shopping”. J of Retailing and Consumer Services 4: 73-81.

39. Medina S, Ward RW (1999) “A model of retail outlet selection for beef". Int Food and Agribusiness Manage Rev 2: 195-219.

40. Outi U (2001) "Consumer perceptions of grocery retail formats and brands". Int J of Retail and Distribution Manage 29: 214-25.

41. Runyon KE, Stewart DW (1987) Consumer Behavior and the Practice of Marketing, Merrill, Columbus, $\mathrm{OH}$.

42. Schiffman LG, Kanuk LK, Hansen H (2008) Consumer behaviour: a European outlook. Harlow: Prentice Hall. 494 p

43. South SJ, Spitze G (1994) "Housework in marital and non-marital households", American Sociological Rev 59: 327-47.

44. Stone KE (1995) Competing with the Retail Giants: How to Survive in the New Retail Landscape, Wiley, New York, NY.

45. Sinha PK, Uniyal DP (2005) "Using observational research for behavioural segmentation of shoppers". J of Retailing and Consumer Services 6:161-73.

46. Sinha PK, Mathew E, Kansal A (2005) "Format choice of food and grocery retailer". Working Paper No. 2005-07-04, IIMA.

47. Woodside AG, Trappey RJ (1992) "Finding out why customers shop your store and buy your brand". J of Advertising Research 32: 59-78.

48. Zeithaml V (1985) “The new demographics and market fragmentation". J of Marketing 49: 64-75. 